Bird Study

\title{
Temporal patterns of bird mortality due to road traffic collisions in a Mediterranean region
}

\section{Pandora Pinto , Rui Lourenço , António Mira \& Sara M. Santos}

To cite this article: Pandora Pinto , Rui Lourenço , António Mira \& Sara M. Santos (2020):

Temporal patterns of bird mortality due to road traffic collisions in a Mediterranean region, Bird Study, DOI: 10.1080/00063657.2020.1779652

To link to this article: https://doi.org/10.1080/00063657.2020.1779652

\section{Published online: 01 Jul 2020.}

Submit your article to this journal $\sqsubset$

Џ Article views: 23

Q View related articles $\llbracket$

View Crossmark data $₫$ 


\title{
Temporal patterns of bird mortality due to road traffic collisions in a Mediterranean region
}

\author{
Pandora Pinto $^{a}$, Rui Lourenço ${ }^{b}$, António Mira ${ }^{c}$ and Sara M. Santos ${ }^{d}$ \\ ${ }^{a}$ UBC - Conservation Biology Lab, Department of Biology, University of Évora, Évora, Portugal; ${ }^{b}$ MED - Mediterranean Institute for Agriculture, \\ Environment and Development, Instituto de Investigação e Formação Avançada, Universidade de Évora, Évora, Portugal; ' Instituto de Ciências \\ Agrárias e Ambientais Mediterrânicas, UBC - Conservation Biology Lab, Department of Biology, University of Évora, Évora, Portugal; ${ }^{\mathrm{d}} \mathrm{MED}$ - \\ Mediterranean Institute for Agriculture, Environment and Development, Conservation Biology Unit, Department of Biology, Universidade de \\ Évora, Évora, Portugal
}

ABSTRACT

Capsule: There was significant variation on the incidence of road traffic mortality across bird species, due to seasonal and weather effects but also due to differences between years.

Aims: To assess patterns of mortality due to traffic collision for six common bird species over a period of nine years in relation to seasonality and weather.

Methods: Road mortality surveys were performed on four road sections from 2005 to 2013 in southern Portugal. The analysis controlled for survey frequency, and carcass persistence and detectability.

Results: Overall, bird mortality decreased over time and was generally higher during spring and summer months. The lack of strong relationships between the weather variables and the observed mortality patterns suggests the existence of additional factors important in explaining the observed trends.

Conclusions: Our study provides evidence that bird mortality due to collision with vehicles may change between years and was highest during the breeding season. This could have population consequences, and highlights the need to further address large temporal scales in roadkill research.
ARTICLE HISTORY

Received 14 November 2018 Accepted 24 January 2020
Biodiversity worldwide is currently facing unprecedented declines due to human activity. For the past 500 years, there has been an increase in extinction rates that far exceed the expected rate based on geological records (Dirzo \& Raven 2003, Hoffmann et al. 2010, Dirzo et al. 2014, Ceballos et al. 2015). Such trends are linked to the major causes of biodiversity loss: habitat change, climate change, spread of invasive alien species, over-exploitation, and pollution (Butchart et al. 2010). Much of the conservation efforts are focused on rare species, since, theoretically, these face higher risk of extinction. Common species, on the other hand, have received far less attention (Gaston 2010, 2011, Inger et al. 2015). Their large numbers make them significant ecosystem shapers - creating, maintaining and modifying habitats - and they are also involved in many biotic interactions and support many ecosystem services, such as decomposition, pollination, pest control, and seed dispersal (Şekercioğlu et al. 2004, Inger et al. 2015). Despite playing key roles in terrestrial and marine ecosystems, common species are greatly affected by habitat loss and degradation, overexploitation and invasive species, often suffering large population and distribution losses (Gaston 2010, 2011). Many examples of this can be found in birds and the decline of common bird species is of growing concern (Donald et al. 2001, Fuller et al. 2005, IUCN 2014, Loss et al. 2015).

According to the 2015 report of the British Trust for Ornithology (BTO), 29 bird species showed a population decline of more than $50 \%$ in recent years (Robinson et al. 2015). In Europe, the monitoring schemes for the last 20 years indicate that species like European Starling Sturnus vulgaris, House Sparrow Passer domesticus, Corn Bunting Emberiza calandra, Woodchat Shrike Lanius senator, European Bee-eater Merops apiaster, and European Serin Serinus serinus, among others, are experiencing moderate declines throughout Europe (Donald et al. 2001, Robinson et al. 2015, Alonso et al. 2019, PECBMS 2019). Furthermore, dwindling avifauna numbers are a worldwide phenomenon. In North America, long-term surveys revealed that approximately 3 billion breeding birds 
disappeared over the last 48 years and an equally sharp decrease of migratory birds passing through the continent since 2007 (Rosenberg et al. 2019). Amongst the most reported ecological causes to explain some of these declines are agricultural intensification and habitat changes (Donald et al. 2001, Robinson et al. 2015, Alonso et al. 2019). However, there are additional anthropogenic factors that negatively affect hundreds of millions of individuals every year, such as predation by domestic cats, hunting, and collision with buildings (Loss et al. 2013, Calvert et al. 2013).

Roads have numerous direct and indirect impacts on birds and have become an issue of great concern in many countries worldwide. The most visible impact of roads on birds is mortality by collision with vehicles, often called 'roadkill' (Forman et al. 2003). It is estimated that between 89 and 340 million birds are killed by traffic each year in the United States of America (Loss et al. 2014), around 10 million in Canada (Calvert et al. 2013), and in some European countries estimates vary from 653,000 in the Netherlands, 1.1 million in Denmark, more than 7 million in Bulgaria, at least 30 million in France, 8.5 million in Sweden, 9.4 million in Germany, and 27 million in England (Erritzøe et al. 2003, Girard 2012). These are impressive numbers and yet very little attention has been given to understand patterns of mortality due to traffic, particularly their temporal trends. Indeed, most studies focus on documenting spatial patterns, concentrating on mortality 'hotspots', which are useful for defining locations for mitigation measures (Malo et al. 2004, Langen et al. 2009). On the other hand, they are commonly conducted over short time periods (1-2 years) and report mostly the seasonal variations in deaths (Smith-Patten \& Patten 2008, Rosa \& Bager 2012). Therefore, it is fundamental to assess if this source of mortality has been changing over the years so we can understand its influence and possible impact on the persistence and viability of populations.

Passerines (Passeriformes) and owls (Strigiformes) are among the taxonomic groups most affected by road traffic deaths (Erritzøe et al. 2003, Benítez-López et al. 2010, Carvalho \& Mira 2011, Grilo et al. 2014). Although some behavioural and ecological characteristics contribute to a higher vulnerability of some species, the most common species are also those most commonly killed by traffic (Møller et al. 2011, D'Amico et al. 2015). In southern Portugal, Santos et al. (2016) found a strong relationship between vulnerability to traffic deaths and foraging behaviour and habitat type in Passeriformes, with the most vulnerable being the small woodland species that feed in shrubs and trees; with a higher than expected mortality for the Goldfinch Carduelis carduelis, Blue Tit Cyanistes caeruleus, and Blackcap Sylvia atricapilla. Owls are also subject of high mortality rate due to traffic, particularly the Tawny Owl (Strix aluco; Silva et al. 2008, 2012, Santos et al. 2013). Traffic mortality has contributed to the reduction of the Barn Owl population in the UK (Ramsden 2003) and in view of that, a high traffic mortality rate for Tawny Owls could be worrying, since this species is a top predator. Thus, if reproduction and immigration are unable to offset the number of deaths on the roads, this could lead to a decline in local abundance and compromise the longterm survival of bird populations.

On the other hand, it is possible that the variation in annual mortality patterns may be partially explained by changes in weather conditions over the years. For example, weather fluctuations may explain differences in food availability for wildlife, which in turn limit animal populations (Fuller et al. 2005, White 2008). Less rainfall translates into lower vegetation growth and consequently lower reproductive success of primary consumers (herbivorous). With a reduced availability of prey, predators must move more and may face greater risk of mortality, such as from collisions with traffic.

In this study, we assessed how the estimates of mortality due to traffic collisions of six bird species varied annually and seasonally, and which weather variables most contributed to the observed variation. In our analysis, we included Goldfinch, Blue Tit, and Blackcap as the species with a higher than expected mortality, plus the Tawny Owl which is the owl species with most casualties in roads near woodlands (Santos et al. 2013). We will also consider the House Sparrow (Passer domesticus) and Corn Bunting (Emberiza calandra), since they are subject to high mortality numbers, but in proportion to their local abundance (Santos et al. 2016). We investigated if there were inter- and intra-annual patterns of road mortality in relation to vulnerability, which we define as an increase of mortality compared to expectations. For the Tawny Owl, it is not known whether mortality is higher or lower than expected. We hypothesized that changes in mortality due to traffic through the years would be more likely to affect the Goldfinch, Blue Tit, and Blackcap (due to their greater vulnerability according to Santos et al. 2016) when compared with the remaining studied species. All species occurred in the study area during the whole year, although the Blackcap is the only species with a considerable population increase during winter from individuals breeding further north, whereas the other species have no considerable changes in population size throughout the year (Catry et al. 2010). 
Methods

\section{Study area}

The study area was in southern Portugal, a typical Mediterranean region, in the district of Évora $\left(38^{\circ} 32^{\prime}\right.$ to $38^{\circ} 47^{\prime} \mathrm{N} 08^{\circ} 13^{\prime}$ to $\left.07^{\circ} 55^{\prime} \mathrm{W}\right)$. The landscape is characterized by woodlands of Cork Oak Quercus suber and Holm Oak Quercus rotundifolia and agricultural areas (arable land, olive groves, and vineyards), with a smooth and undulating relief (under $400 \mathrm{~m}$ above sea level). The climate is typically Mediterranean with hot, dry summers, and mild winters with annual rainfall averaging $609.4 \mathrm{~mm}$. During summer (in July), mean temperature varies from $16.3^{\circ} \mathrm{C}$ to $30.2^{\circ} \mathrm{C}$ and in winter (January) it fluctuates between $5.8^{\circ} \mathrm{C}$ and $12.8^{\circ} \mathrm{C}$ (Évora 1981-2000, IPMA 2017a). The road traffic mortality surveys were performed on four road sections (N4, N114, M529, and M370), totalling $37 \mathrm{~km}$ between Évora and Montemor-o-Novo (online Figure S1).

\section{Mortality dataset}

Road surveys were performed by an experienced observer driving a car at low speed $(20-40 \mathrm{~km} / \mathrm{h})$ and starting at sunrise, from 2005 to 2013. The frequency of surveys varied between daily (2005; 16th March 2009 to 31th October 2009; 16th March 2010 to 22nd March 2013) and weekly (2006-2008; November 2009 to 15th March 2010, and May to December 2013). No surveys were done during the month of April 2013. Every carcass found was identified to the lowest taxonomic level and its coordinates were recorded using a handheld global positioning system (GPS) device. For more survey details see Santos et al. $(2011,2013,2016)$. Due to the temporal extension of these surveys, it was not always possible to guarantee the same observer, however, methods were standardized to minimize variation between observers, and new observers received two weeks training before performing the survey alone.

\section{Explanatory variables}

In order to assess the influence of weather conditions on the interannual variation of mortality patterns, we selected the following variables: year, month, mean monthly maximum temperature $\left({ }^{\circ} \mathrm{C}\right.$; hereafter 'mtmax'), mean monthly minimum temperature $\left({ }^{\circ} \mathrm{C}\right.$; 'mtmin'), total monthly rainfall ( $\mathrm{mm}$; 'rainfall'), and the difference in monthly rainfall in relation to mean annual value ('rain_sd'). Values for all weather variables were obtained from Instituto Português do Mar e da Atmosfera (IPMA 2017a).

\section{Data analysis}

\section{Data organization}

The dataset was first organized as a time series, with each observation being a monthly count of observed corpses and starting in January 2005. Thus, we built six datasets, one for each species. When assessing mortality counts there are a number of factors that affect the probability of finding a carcass and, ultimately, can lead to an underestimation of mortality (Santos et al. 2011, Teixeira et al. 2013). Considering that the surveying periodicity varied over the years and smaller birds quickly disappear from roads (Santos et al. 2011, Teixeira et al. 2013), it was necessary to calibrate the counts of dead birds found. Carcass detection probability was obtained using a Huso estimator that combined the carcass persistence probability, the observer efficiency, and the survey interval (Korner-Nievergelt et al. 2015). It is then possible to estimate the number of animals that have died from the number of carcasses counted and the carcass detection probability. We defined daily persistence probability of 0.366 for passerine and 0.745 for owl carcasses (Santos et al. 2011). There were no experimental data available for observer efficiency, but we considered 0.8 for passerines and 1.0 for owls, meaning that, being present on the road, passerines are 1.25 times harder to find than owls due to their smaller size. We used the Horvitz-Thompson function (HT; equals the number of carcasses found divided by the detection probability) within the Huso estimator to calculate the number of carcasses in each month. It was assumed that carcasses arrive only at the beginning of each time interval (Korner-Nievergelt et al. 2015).

\section{General mortality trends}

To characterize mortality patterns of species, temporal trend graphics were produced for each species and generalized linear models (with Poisson link) were adjusted to visualize the mortality trends. The significance of trends was assessed through the time coefficient and amount of explained deviance $\left(D^{2}\right)$ for each species. To assess the differences between coefficients for the time trend, it was interpreted as significantly different if there was no overlap in $95 \%$ confidence intervals among species.

\section{The influence of variables on mortality on roads}

A preliminary selection of explanatory variables was done with exploratory plots and Pearson correlations that were calculated to check for collinearity (Zuur et al. 2010). For each pair of highly correlated variables $(|\mathrm{rs}|>0.7)$, only the one with the higher correlation 
with response variables was retained for further analysis (Tabachnick \& Fidell 1996). Accordingly, mtmin and rain_sd were discarded. A logarithmic transformation was applied to rainfall to remove outliers and improve normality. The response variable 'mortality numbers', being count data, was modelled with a Poisson distribution. As we had a temporal data series, we used generalized additive mixed models (GAMM) to incorporate the temporal correlation component of the data and also include a Poisson link and non-linear effects (Zuur et al. 2007, 2009). We used autoregressive (AR) and auto-regressive moving average (ARMA) models with a residual correlation structure (using alternatively, year or month) to determine the influence of year, season, and weather conditions on mortality trends (Zuur et al. 2009). The correlation structure that yielded a model with the lowest Akaike's Information Criteria (AIC) was selected. After selecting the best residual correlation structure, the most informative fixed effects were evaluated. All explanatory variables were initially entered as smoothing terms and only remained in the model as such if significant $(P<0.05)$ and non-linear $($ edf $>2)$. The linear significant explanatory variables $($ edf $<2)$ were kept in the model as linear terms (without the smoothing term). The final model for each species was selected using AIC, and an assessment of goodness of fit was made with residual plots and amount of explained deviation (Burnham \& Anderson 2002, Zuur et al. 2009). The explanatory variables included in the models as non-linear (smooth) terms are graphically presented indicating their additive effect on the mortality numbers in the vertical axis (written as $\mathrm{s}$ (name of variable, number of degrees of freedom)). The term ' $s$ ' is a thin plate regression spline (Wood 2017).

Estimates and calculations of carcass detection probability were conducted with 'carcass' $\mathrm{R}$ package (Korner-Nievergelt et al. 2014, Korner-Nievergelt et al. 2015). Mixed models were applied using 'mgcv' package (Wood 2017). All analyses and graphical outputs were performed with $\mathrm{R}$ version 3.3.0 (R Development Core Team 2016).

\section{Results}

A dataset of 2533 traffic-killed birds of target-species, was recorded between 1 January 2005 and 31 December 2013. From the total of surveyed birds, $26.6 \%$ of these were Blue Tits $(n=674), 19.5 \%$ Blackcaps $(n=494), \quad 15.7 \%$ Goldfinches $(n=398)$, $14.5 \%$ Tawny Owls $(n=368), 12.2 \%$ House Sparrows $(n=308)$, and $11.5 \%$ Corn Buntings $(n=291$; see online Table S1).

From these initial 2533 carcasses, the estimated actual number increased substantially to 7438 after accounting for survey frequency, carcass persistence time, and observer detectability errors (Korner-Nievergelt et al. 2014, online Figure S2). After correcting our traffic mortality estimates, the Blue Tit and Blackcap were the species with highest mortality numbers, accounting for $27.7 \%(n=2060)$ and $25.8 \%(n=1918)$ of the total number of deaths, respectively. The Goldfinch, Corn Bunting, and the House Sparrow had intermediate levels of mortality with $14.9 \%(n=1106), 12.7 \%(n=$ $942)$ and $12.6 \% \quad(n=935)$ of total mortality, respectively. Among the species considered in this study, the Tawny Owl had the lowest estimated mortality, but still accounting for $6.4 \%(n=477)$ of the mortality due to road traffic.

\section{General mortality trends}

There was a general decreasing and significant trend in the number of deaths due to traffic for all species studied from 2005 to 2013 (Figure 1). This decreasing trend was highest in the Blackcap (GLM coefficient = $-0.016 ; P<0.001)$ and lowest in the Blue Tit and Goldfinch (GLM coefficient $=-0.008 ; P<0.001$ ). The proportion of explained deviance followed a similar trend: highest in the Blackcap $\left(\mathrm{D}^{2}=0.156\right)$ and lowest in the Goldfinch $\left(D^{2}=0.035\right)$. Although the difference between the coefficients was small, it was significant (non-overlapping confidence intervals) between some species pairs: the negative trend for Blackcap was stronger than for the remaining species (Figure 2). Also, the coefficient values (trend) of species 'vulnerable to traffic mortality' (Goldfinch, Blue Tit, Blackcap) were not significantly different from the 'non-vulnerable' species group (House Sparrow and Corn Bunting) and from the Tawny Owl, as there was overlap among estimated 95\% confidence intervals of coefficients (Figure 2). Even omitting the Blackcap, the negative trend of Corn Bunting and House Sparrow was stronger than that for the Blue Tit, thus not supporting our initial hypothesis that the species vulnerable to mortality due to traffic would have a stronger decline in mortality (Figure 2).

The patterns of road traffic mortality were not regular within years and there were seasonal patterns in deaths for all species (some months with very high death estimates and others with minimum estimates; Figure 3). In general, mortality due to traffic increased during spring and summer months, except for the Blackcap, for which the mortality pattern peaked in January. The 

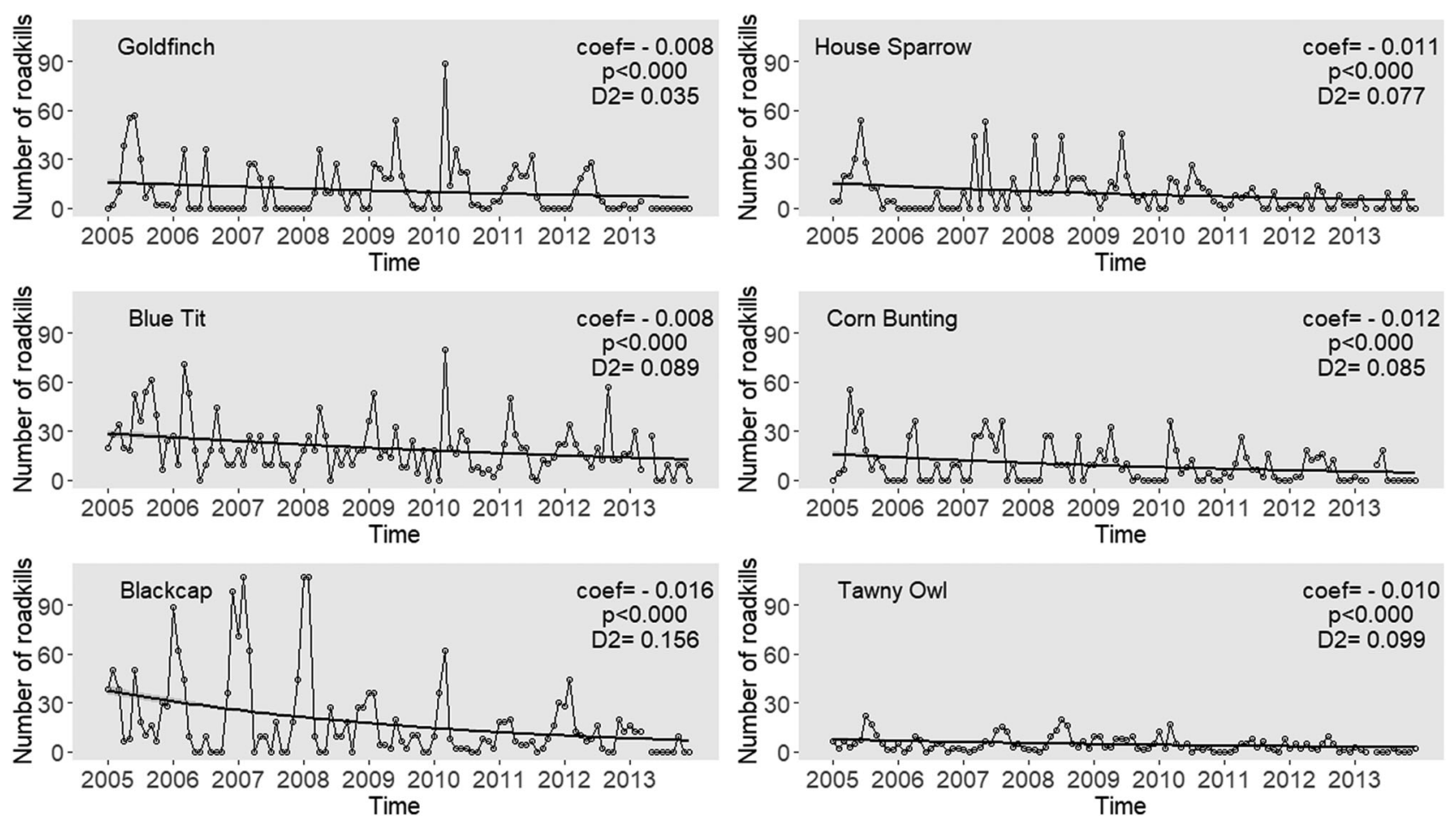

Figure 1. Annual trends of the estimated mortality caused by roadkills for Goldfinch, Blue Tit, Blackcap, House Sparrow, Corn Bunting, and Tawny Owl for nine years (2005-2013). A Poisson GLM model was fitted for each species. The respective coefficient (coef), its significance $(p)$ and explained deviance $\left(D^{2}\right)$ are displayed.

Goldfinch, Corn Bunting, and House Sparrow showed similar patterns, being killed more frequently between March and July, with much lower numbers of traffic deaths during the remaining months. Comparatively to the other species, the mortality in the Blue Tit was rather constant throughout the year, slightly increasing in spring and summer. Deaths of Tawny Owls were higher during summer, peaking in July and August, though there was also a slight increase in January.

\section{The influence of weather variables on mortality trends}

The best GAMM model for the Blue Tit, Corn Bunting, and House Sparrow was an auto-regressive model incorporating temporal dependence between consecutive months (Table 1). The best model for the Tawny Owl incorporated a temporal dependence between years, while the best model for the Goldfinch and Blackcap was an auto-regressive moving average (ARIMA) model (Table 1). The models showed good fit to the traffic mortality time series data after inspection of residual plots. The amount of variance explained was good for the Blackcap, Corn Bunting, and Goldfinch (between 53.2\% and 68.7\%), but lower for the Blue Tit, House Sparrow, and Tawny Owl (between 23.8\% and 33.6\%; Table 1).
Mortality estimates of the Goldfinch through time were best explained by year, month, temperature, and rainfall (Figure 4). From 2005 to 2007 there was a steep decrease in mortality, although reaching high values in 2010, and decreasing again from 2011 onward. There was also a seasonal effect within the year, with mortality peaking in March-June. Months with temperatures around $15-20^{\circ} \mathrm{C}$ and higher than $30^{\circ} \mathrm{C}$ had higher probability of increased mortality of Goldfinches. The effect of rainfall was less clear but indicates that mortality was higher above 4 in the graph (Figure 4), which after logarithmic back transformation $\left(e^{4}+1\right)$, means approximately $50 \mathrm{~mm}$ of monthly rainfall. The trend in mortality estimates of the Blue Tit was best explained by year, month, temperature, and rainfall (Figure 5). Mortality for this species was highest in 2005 and decreased afterwards up till 2008. From here on, it slightly increased until 2011, which was followed by another decrease. There is also a seasonal effect within the year, with higher levels of mortality in March-April and again in SeptemberOctober. The effects of temperature and rainfall are more subtle, but results indicate that mortality was higher at temperatures lower than $17^{\circ} \mathrm{C}$ and higher than $30^{\circ} \mathrm{C}$, while rainfall had the same effect at monthly values around $2-7 \mathrm{~mm}$ and $50-90 \mathrm{~mm}$. Deaths of the Blackcaps due to traffic were best 


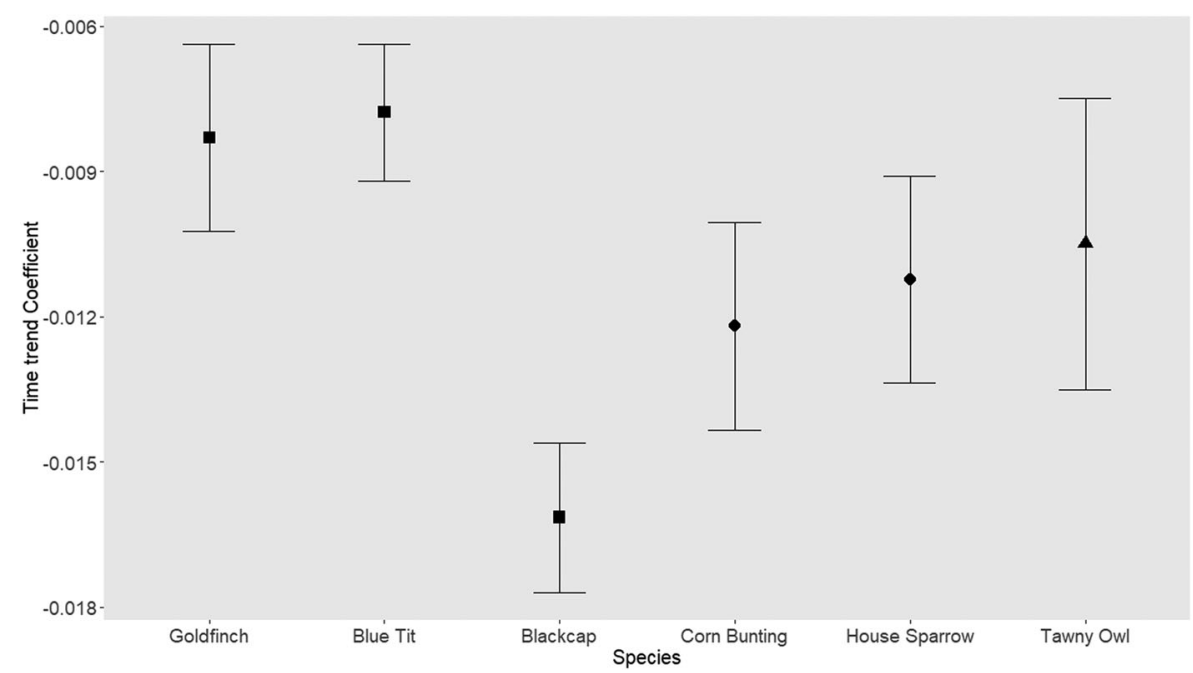

Figure 2. Comparison of GLM coefficients (and respective $95 \%$ confidence intervals) of annual trends of the estimated mortality for the six species under study (square symbol: species with higher than expected mortality - 'vulnerable'; diamond symbol: species road-killed in proportion to their abundance; triangle symbol: species with no information on expected mortality).

explained by year, month, temperature, and rainfall (Figure 6). Mortality decreased along the years, being highest between 2005 and 2007. There is evident seasonality in the mortality pattern of Blackcaps, with more deaths recorded in winter months. In respect to the weather variables, mortality increased between 2$7 \mathrm{~mm}$ and for more than $55 \mathrm{~mm}$ of rainfall per month, and when temperatures are between $10^{\circ} \mathrm{C}$ and $17^{\circ} \mathrm{C}$ and $27^{\circ} \mathrm{C}$ and $34^{\circ} \mathrm{C}$. Mortality of the House Sparrow was best explained by year, month and rainfall (Figure 7). There was a decrease in mortality from 2005 to 2006, followed by a peak between 2008 and 2010, after which it decreased again. Mortality was also highest from March to August. The effect of rainfall on the number of traffic deaths of House Sparrows was not very strong, but for values lower than $55 \mathrm{~mm}$, mortality seemed to decrease. The mortality of Corn Buntings was best explained by year, month,
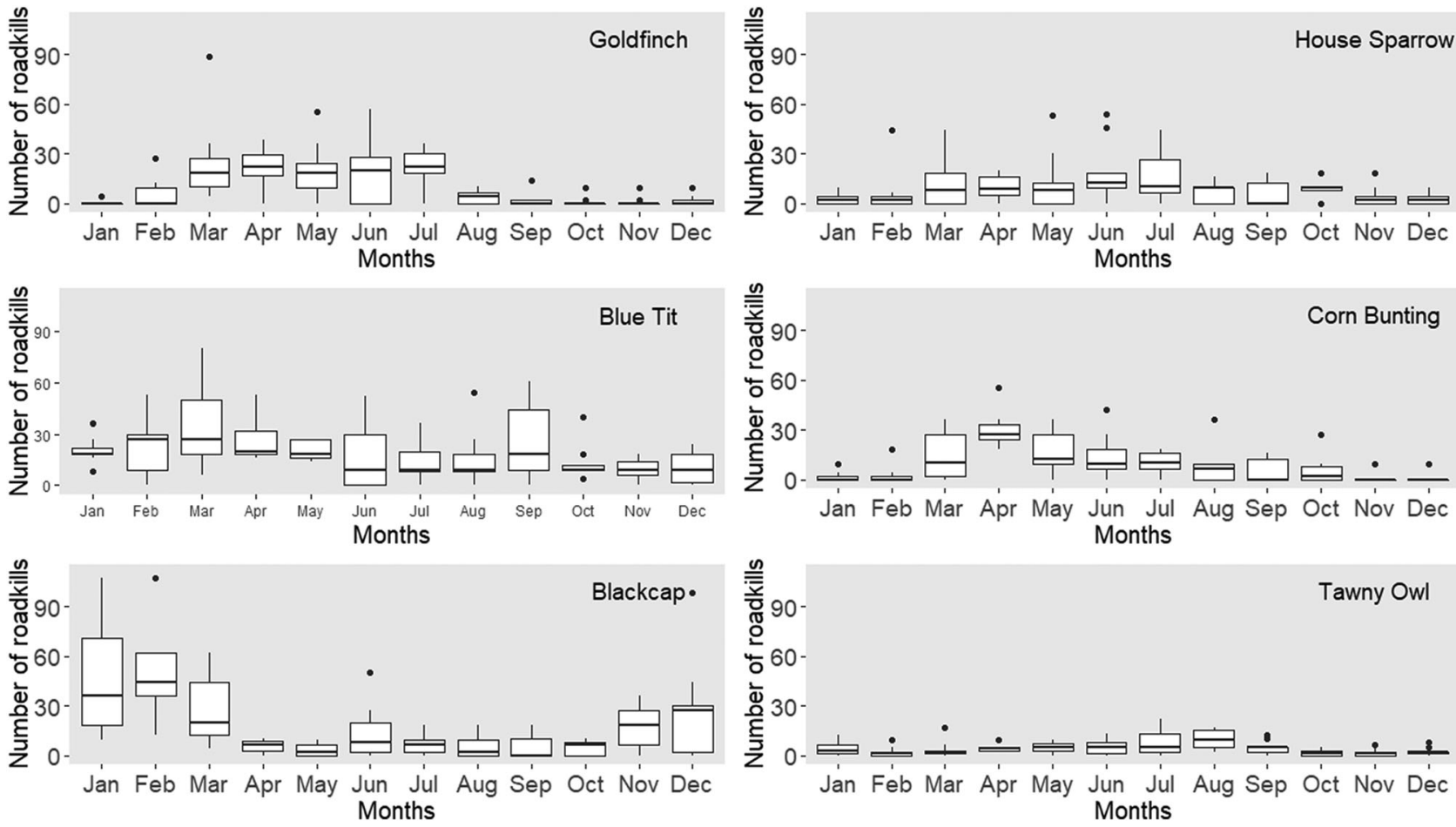

Figure 3. Seasonal trends of the estimated mortality caused by roadkills for Goldfinch, Blue Tit, Blackcap, House Sparrow, Corn Bunting, and Tawny Owl. 
Table 1. Summary of GAMM results with parameters of explanatory variables included in final models for each species (Parameters of the smooth terms: Edf: estimated degrees of freedom of non-linear (smooth) terms, F: F test of non-linear terms, $p$-value: significance of $F$ test of non-linear terms; Parameters of the linear terms: Coef: regression coefficient of linear terms, $t: t$ test for significance of linear coefficient, $p$-value: significance of $t$ test of linear terms. Phi: parameters referring to the residual correlation structure (for ARIMA models there are two auto-regressive parameters). Corr str: residual correlation structure incorporated in the model (ARIMA: autoregressive moving average for temporal dependence with parameters $(2,0)$ and $(1,0)$; AR: auto-regressive model incorporating temporal dependence between consecutive months or years). $\mathrm{R}^{2}$ adj.: percentage of explained deviation of model (\%)).

\begin{tabular}{|c|c|c|c|c|c|c|c|c|c|c|}
\hline \multirow{2}{*}{ Species } & \multirow{2}{*}{ Variables } & \multicolumn{3}{|c|}{ Smooth terms } & \multicolumn{3}{|c|}{ Linear terms } & \multirow{2}{*}{ Phi } & \multirow{2}{*}{ Corr str } & \multirow{2}{*}{$\mathrm{R}^{2}$ adj } \\
\hline & & Edf & $F$ & $p$-value & Coef & $\mathrm{t}$ & $p$-value & & & \\
\hline \multirow[t]{4}{*}{ Goldfinch } & Year & 3.930 & 56.013 & $<0.001$ & & & & $0.06 ;-0.06$ & $\operatorname{ARIMA}(2,0)$ & 54.7 \\
\hline & month & 3.868 & 105.267 & $<0.001$ & & & & & & \\
\hline & rainfall & 3.277 & 8.571 & $<0.001$ & & & & & & \\
\hline & $\operatorname{mtmax}$ & 3.895 & 26.630 & $<0.001$ & & & & & & \\
\hline \multirow[t]{4}{*}{ Blue Tit } & year & 3.718 & 28.660 & $<0.001$ & & & & -0.05 & $\mathrm{AR}$ (month) & 23.8 \\
\hline & month & 3.851 & 67.080 & $<0.001$ & & & & & & \\
\hline & rainfall & 3.826 & 8.724 & $<0.001$ & & & & & & \\
\hline & $\operatorname{mtmax}$ & 3.531 & 3.262 & 0.0099 & & & & & & \\
\hline \multirow[t]{4}{*}{ Blackcap } & year & 3.847 & 95.990 & $<0.001$ & & & & $-0.08 ; 0.86$ & $\operatorname{ARIMA}(1,0)$ & 68.7 \\
\hline & month & 3.686 & 43.115 & $<0.001$ & & & & & & \\
\hline & rainfall & 3.730 & 9.662 & $<0.001$ & & & & & & \\
\hline & $\operatorname{mtmax}$ & 3.975 & 47.416 & $<0.001$ & & & & & & \\
\hline \multirow[t]{3}{*}{ House Sparrow } & year & 3.933 & 66.541 & $<0.001$ & & & & -0.07 & AR(month) & 25.2 \\
\hline & month & 3.636 & 51.747 & $<0.001$ & & & & & & \\
\hline & rainfall & 2.896 & 9.805 & $<0.001$ & & & & & & \\
\hline \multirow[t]{4}{*}{ Corn Bunting } & year & & & & -0.12 & -6.340 & $<0.001$ & -0.04 & AR(month) & 53.2 \\
\hline & month & 3.937 & 164.620 & $<0.001$ & & & & & & \\
\hline & rainfall & 3.886 & 11.870 & $<0.001$ & & & & & & \\
\hline & $\operatorname{mtmax}$ & & & & -0.06 & -3.085 & 0.003 & & & \\
\hline \multirow[t]{4}{*}{ Tawny Owl } & year & 3.060 & 13.076 & $<0.001$ & & & & 0.16 & AR(year) & 33.6 \\
\hline & month & 3.745 & 6.757 & $<0.001$ & & & & & & \\
\hline & rainfall & & & & -0.08 & -1.703 & 0.092 & & & \\
\hline & $\operatorname{mtmax}$ & & & & -0.05 & -2.013 & 0.047 & & & \\
\hline
\end{tabular}

temperature, and rainfall (Figure 8). Mortality decreased linearly through the time period (negative coefficient) and decreased also with higher temperatures (Table 1). Within the year, mortality started to increase at the beginning of the year, peaking from April to June and decreasing afterwards. For monthly values of rainfall between 2 and $7 \mathrm{~mm}$ and 55 and $148 \mathrm{~mm}$, the number of traffic deaths of Corn Buntings increased. Mortality of the Tawny Owl through the study period was best explained by year, month, temperature, and rainfall, the last two with linear effects (Figure 9). Mortality lightly decreased from 2005 to 2007 , remaining stable until 2010, when a steep decrease occurred. There was a seasonal effect within the year with mortality increasing in March and peaking between June and August, followed by a decline. Rainfall and maximum temperature were negatively correlated with mortality $(-0.08$ and -0.05 , respectively; Table 1$)$, so mortality due to traffic increased during cold and dry months.

\section{Discussion}

Our results revealed an overall decreasing trend in the number of deaths due to road traffic collisions from 2005 to 2013 for all studied species, although slightly more evident in the Blackcap. However, the differences detected did not support our proposed hypothesis: the three most vulnerable species (i.e. with higher than expected mortality: Goldfinch, Blue Tit, and Blackcap) did not show a stronger decline when compared to species that are killed by traffic in proportion to their abundance (House Sparrow and Corn Bunting, Santos et al. 2016).

While the mortality pattern was not the same throughout the years, all species showed marked seasonality in the number of deaths due to traffic. The effects of weather variables were less evident, when compared to time and season, and differed across the species, which may suggest the existence of additional factors important to explain the observed trends.

\section{The declining trend of roadkills}

The overall declining trend in the number of deaths due to traffic collisions in our study area can result from three non-exclusive main explanations: (1) a reduction in bird populations near roads due to their negative effects; (2) a general negative population trend in bird species due to broad-scale effects (e.g. climate change, habitat change); and (3) a decrease in traffic volume during the study period.

Concerning the first explanation, many studies mention road characteristics (e.g. traffic density, speed, and road width) playing a key role in shaping road 


\section{Goldfinch Carduelis carduelis}
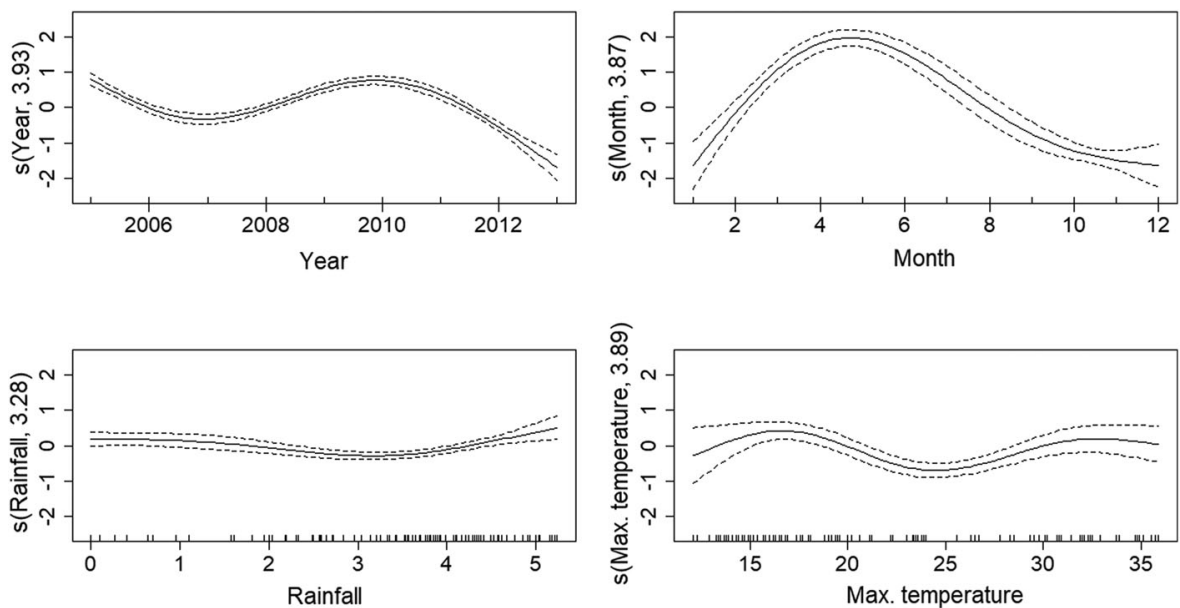

Figure 4. Non-linear factors affecting the temporal distribution of roadkills for Goldfinch. Fitted smooth terms (written as s(name of variable, number of degrees of freedom)) for Goldfinch mortality (solid lines) and confidence intervals (dashed lines); top left panel: year, top right panel: month, bottom left panel: rainfall, bottom right panel: maximum temperature.

casualties and population density near roads (Clevenger et al. 2003, Erritzøe et al. 2003, Husby 2017). The Tawny Owl is often less abundant or absent in the proximity of roads with high traffic density due to factors such as traffic disturbance, loss of habitat quality, and habitat fragmentation (Silva et al. 2012). The number of fledglings per breeding attempt of Great Tits Parus major can be reduced in areas adjacent to fast and frequent traffic due to the death of the parent birds on roads (Holm \& Laursen 2011). Great Bustard Otis tarda populations in Portugal are concentrating geographically, and one of the reasons for the local population declines is road building (Pinto et al. 2005). Thus, birds may respond to roads with strong declines in local density (Reijnen et al. 1997, Parris \& Schneider 2009, Kociolek et al. 2011, Polak et al. 2013). Bird abundance near roads could also be affected by the surrounding habitats and their quality (Erritzøe et al. 2003, Orłowski 2008, Rosa \& Bager 2012, Santos et al. 2016). The value of roadside vegetation and hedgerows for birds has been subject to some discussion. Some studies show their positive role in transforming roadsides into suitable habitats (Morelli et al. 2014, 2015), while others highlight the higher mortality in such areas (Orłowski 2008). Roadside vegetation is used by many bird species as a breeding, foraging, and resting area (Laursen 1981), but it can potentially act as an ecological trap. This is of importance when certain

\section{Blue Tit Cyanistes caeruleus}
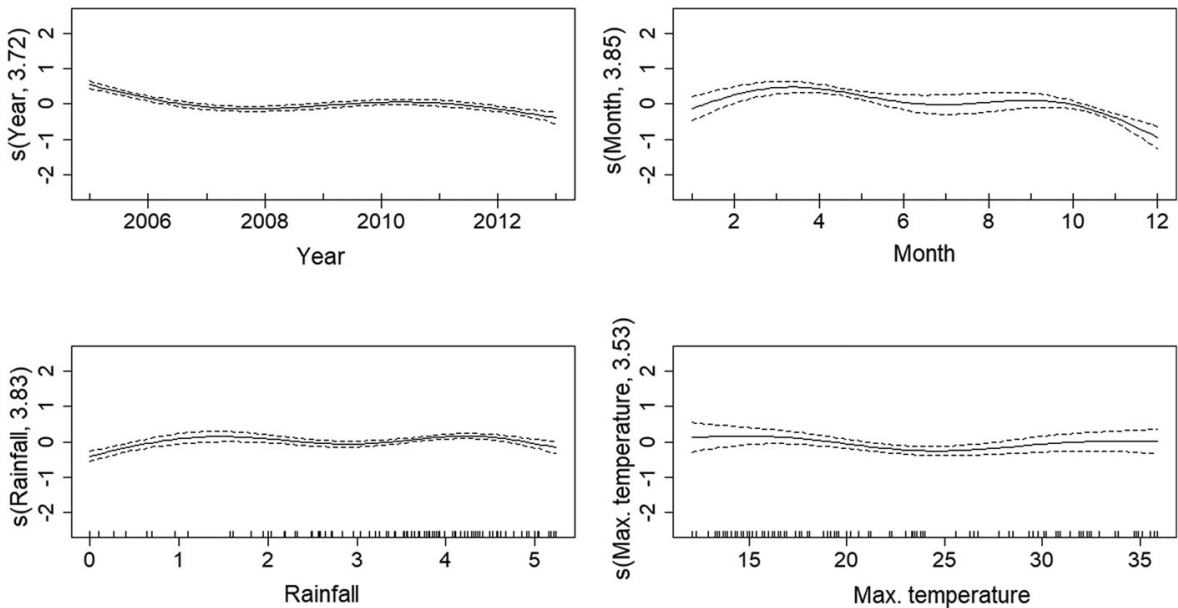

Figure 5. Non-linear factors affecting the temporal distribution of roadkills for Blue Tit. Fitted smooth terms (written as s(name of variable, number of degrees of freedom)) for Blue Tit mortality (solid lines) and confidence intervals (dashed lines); top left panel: year, top right panel: month, bottom left panel: rainfall, bottom right panel: maximum temperature. 


\section{Blackcap Sylvia atricapilla}
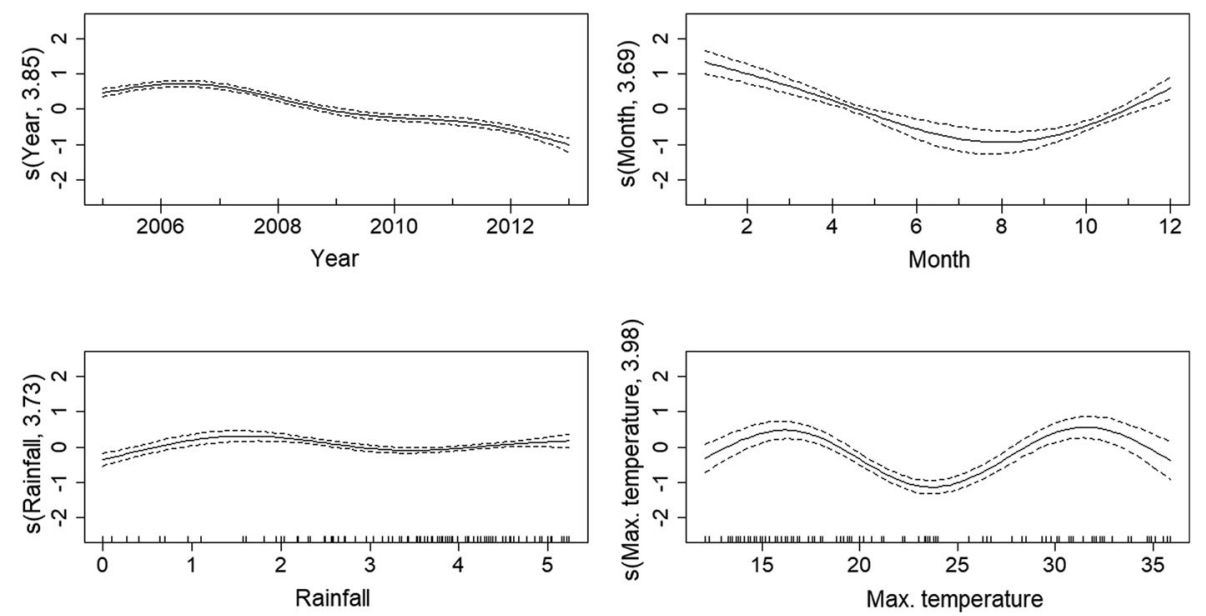

Figure 6. Non-linear factors affecting the temporal distribution of roadkills for Blackcap. Fitted smooth terms (written as s(name of variable, number of degrees of freedom)) for Blackcap mortality (solid lines) and confidence intervals (dashed lines); top left panel: year, top right panel: month, bottom left panel: rainfall, bottom right panel: maximum temperature.

habitat types (e.g. woody vegetation in cropland borders) are only present along the communication routes, attracting birds to the area and potentially making them more vulnerable to road traffic (Orłowski 2005, 2008). However, this seems to be an unlikely explanation in our case as habitat quality of areas crossed by the roads was high overall (Silva et al. 2012, Santos et al. 2013, 2016, Salgueiro et al. 2018). Although there have been no significant changes in the landscape that could justify a decrease in bird abundance (S. Santos, pers. obs.), in recent years, especially since forest fires of 2005, the frequency of vegetation cutting on road verges has increased in Portugal (A. Mira, pers. obs.). Therefore, this may have contributed to reduce the attractiveness of road verges to most birds, which in turn could contribute to reduce the number of road casualties.

Regarding the second explanation (i.e. broad-scale population changes), this could apply mostly to the Blackcap, since a reduction in mortality throughout the years could result from differences in migration flows due to strong worldwide trends and climate change. Many studies report an association between bird migratory phenology and weather variables, with the recent shifts in migration periods being a response to climate change (Gordo 2007, Jonzén et al. 2007). The Blackcap shows a moderate increasing trend in Portugal and elsewhere in Europe (Alonso et al. 2019, PECBMS 2019), which is not consistent with its negative trend as roadkill. Nevertheless, there can be a regional decrease in the wintering population of the Blackcap as a result of range compression in wintering distribution (Fando \& Telleria, 2018). Although we have no data available and it would require future verification, the decrease in mortality from collision with vehicles could also be a consequence of a local or regional decline in the resident populations of the Blackcap. The House Sparrow is one of the most frequently reported species killed by traffic, both in neotropical and temperate zones (Erritzøe et al. 2003, Rosa \& Bager 2012). Despite its large range in Europe, House Sparrows have been declining since 1980 (De Laet \& Summers-Smith 2007, BirdLife International 2017). Similarly, the European trend of the Corn Bunting also shows a population decline. However, the other target-species are either stable or show moderate increases in their numbers across Europe and Portugal (Meirinho et al. 2013, SEO/BirdLife 2014, GTANSPEA 2016, BirdLife International 2017). Thus, a general decreasing trend in roadkills seems unexpected, unless the regional trend of populations is somewhat different to the national trend. Still, we should consider the possibility that population trends near and far from main roads may have opposite directions - despite a general population increase, abundance near main roads might be declining from continuous and accumulated effect of mortality and disturbance.

Regarding the last hypothesis (decrease in traffic volume), the probability of collision between a bird and a vehicle is likely to increase with traffic volume (Clevenger et al. 2003), thus reducing the survival rate of birds in roadside habitats. In Portugal no estimate is available for the trend of traffic volume (ITF 2016), so we cannot accurately assess the influence of traffic volume changes on shaping mortality throughout the years in our study area. However, from 2008 to 2010 almost all species showed a decline in mortality which 
House sparrow Passer domesticus
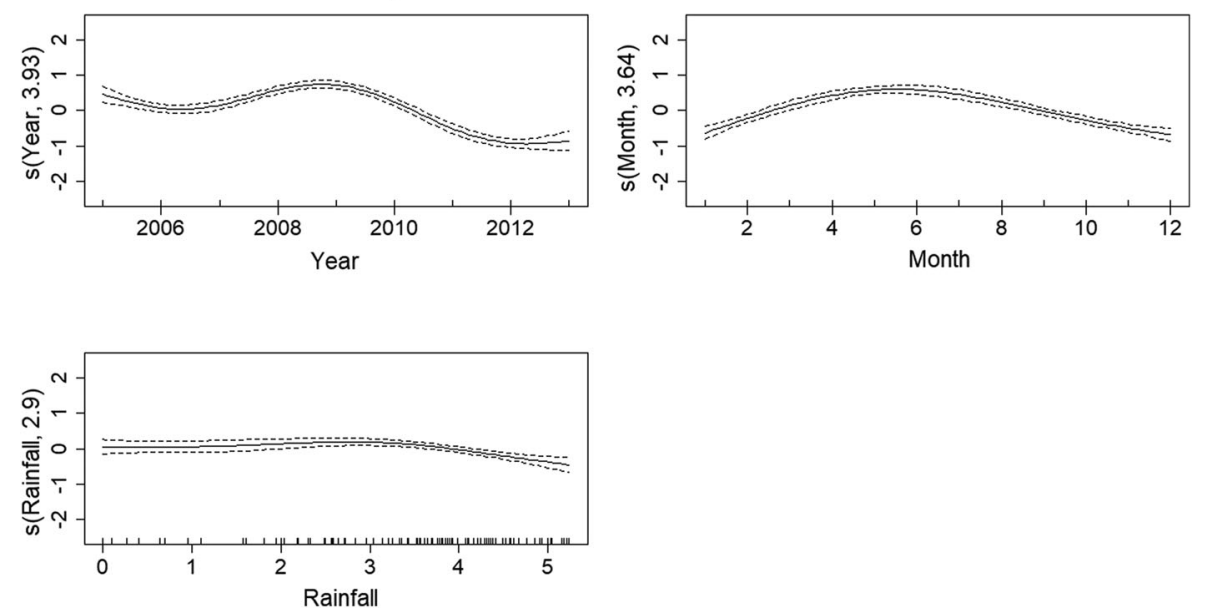

Figure 7. Non-linear factors affecting the temporal distribution of roadkills for House Sparrow. Fitted smooth terms (written as s (name of variable, number of degrees of freedom)) for House Sparrow mortality (solid lines) and confidence intervals (dashed lines); top left panel: year, top right panel: month, bottom left panel: rainfall.

could be related to a decrease in traffic volume due to the recent economic crisis. In Spain, there was a decrease by $14 \%$ of the traffic volume between 2007 and 2013, and the number of registered vehicles also slightly decreased as a result of the economic downturn (ITF 2016). Portugal was also affected by this crisis so possibly the same traffic drop occurred at the time, which may have led to a decrease in roadkills.

The role mortality alone plays in reducing bird densities near roads is sometimes dismissed (Reijnen \& Foppen 2006), perhaps because it is correlated with other factors that are often difficult to disentangle. But some studies have suggested that traffic mortality is the main factor contributing to the decline in bird abundances (Summers et al. 2011, Jack 2013). Considering that mortality numbers can be quite high

\section{Corn bunting Emberiza calandra}
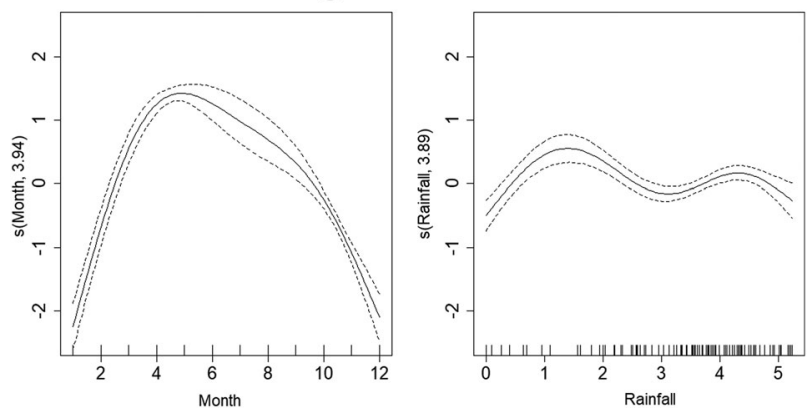

Figure 8. Non-linear factors affecting the temporal distribution of roadkills for Corn Bunting. Fitted smooth terms (written as $\mathrm{s}$ (name of variable, number of degrees of freedom)) for Corn Bunting mortality (solid lines) and confidence intervals (dashed lines); left panel: month, right panel: rainfall. for some species, it is possible that after a while, roadkills may exert selection, favouring individuals that either learn to avoid roads or have characteristics that allow them to avoid vehicles, and thus reduce the number of casualties. In the Cliff Swallow Petrochelidon pyrrhonota in Nebraska, USA, a decline in road mortality observed over 30 years could not be explained by decreases in abundance or traffic volume. It resulted from a selective mortality favouring individuals whose wing morphology (larger wing length) allowed for a better escape from vehicles (Brown \& Brown 2013).

\section{Seasonality of roadkills}

The seasonal patterns of roadkills observed for the six species seem mainly associated with the phenological
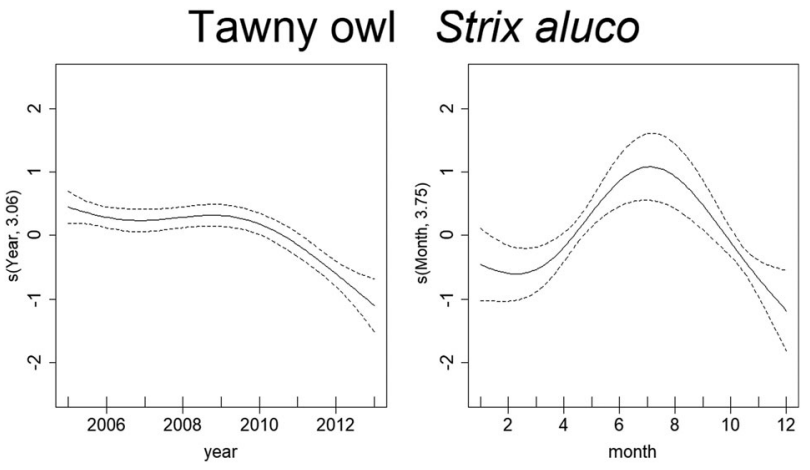

Figure 9. Non-linear factors affecting the temporal distribution of roadkills for Tawny Owl. Fitted smooth terms (written as s (name of variable, number of degrees of freedom)) for Tawny Owl mortality (solid lines) and confidence intervals (dashed lines); left panel: year, right panel: month. 
traits that make them more vulnerable to collision with vehicles, as reported in previous studies (Carvalho \& Mira 2011, Rosa \& Bager 2012, Garriga et al. 2017). For the five species that are resident in the study area, mortality generally peaked in spring-summer, mostly between April and September. This corresponds to the periods of breeding activity (incubation and fledging) and juvenile dispersal (Erritzøe et al. 2003, del Hoyo et al. 2015). This last period results in an increase in abundance of individuals (especially inexperienced ones), which may explain the increased mortality (Erritzøe et al. 2003, Grilo et al. 2014). Particularly in the case of the Tawny Owl, the number of roadkills seems greater during post-natal dispersal, suggesting that juvenile individuals are more vulnerable to collision with vehicles than adults. In our study area, juveniles may represent $56 \%$ of the Tawny Owl casualties along the year (Santos et al. 2013). On the other hand, during the fledging period, adults need to do frequent movements, and often longer ones, to be able to feed their young, which may cause birds to cross roads more frequently, or use road verges to search for food, potentially increasing mortality risk (Kuitunen et al. 2003, Holm \& Laursen 2011). When considering all bird species, from November to January there may be fewer individuals killed as the migratory species head south. However, when most trans-Saharan migrants are already in Africa, many birds of common species coming from higher latitudes arrive (Elphick 2007). In many cases, this wintering contingent increases the ranks of the resident population. This is the case for the Blackcap which our results show to die more during the winter months, a period when there is a large population increase due to the arrival of birds breeding in central and northern Europe and wintering in southern Europe (Cramp \& Brooks 1992).

Another possible explanation for higher bird mortality on roads during spring-summer is the intensification of traffic volume during this period, or a greater overlap of traffic peaks with day periods of higher bird activity (Erritzøe et al. 2003). During winter, on the other hand, there is a shorter length of daylight and generally less traffic (Erritzøe et al. 2003). An increase in food availability near roads for seed-eating birds due to agricultural crops and harvest during summer months may also explain higher bird mortality (Erritzøe et al. 2003, Rosa \& Bager 2012). The flocking behaviour observed outside the breeding season for some species (e.g. Goldfinch, Corn Bunting) could also influence vulnerability to traffic (Lima \& Dill 1990, Møller et al. 2011, Cook \& Blumstein 2013). Lastly, when comparing roadkills from different countries for some species, it is important to consider that seasonal patterns of avian mortality may vary from place to place as a result of geographical variations in their ecology and phenology (Erritzøe et al. 2003).

\section{Relationship between roadkills and weather}

Despite the role weather plays in many aspects of the life traits and activity patterns of birds, very few studies considered its influence in road fatalities. We might expect that more extreme weather conditions, such as the severe drought verified in Portugal in 2005 (GarcíaHerrera et al. 2007, Climatic Characterization of the Year 2005, IPMA 2017b), would have a considerable impact on population density and space use due to limited resources and, thus, enhance road casualties (Erritzøe et al. 2003). Weather conditions affect the metabolic rate of birds (e.g. cold weather requires more energy to maintain body functions) and can influence foraging conditions (Crick 2004). Therefore, roads could be attractive to animals during more extreme weather conditions, increasing their likelihood of being hit, by offering cover and food because of moister conditions and more abundant vegetation on verges, in contrast to the surrounding areas (Erritzøe et al. 2003, Orłowski 2005, Morelli et al. 2014).

Our results suggest a correlation between roadkills and rainfall and temperature for most species. Garriga et al. (2017) reported similar results in northeast Iberia, with bird roadkills being positively associated with temperature and negatively related to humidity and irradiation. However, in our study, the relationship with rainfall and temperature was not so clear, which may suggest that there are other factors with greater influence on the number of bird roadkills.

\section{Conclusions}

The decline in roadkills over nine years we observed in six common species provides concrete data that mortality due to collision with vehicles changes over time. Road raffic collisions are a significant source of mortality for birds, mainly during the breeding period, and the lack of information on its demographic consequences poses a severe threat to the long-term survival of animals in road habitats. This requires continuous monitoring of roadside populations and road features. The estimated mortality for the Tawny owl (a predator) was just half of that of three common passerines (Goldfinch, Corn Bunting, and House Sparrow), suggesting that Tawny Owls are particularly vulnerable to death from traffic collisions. The overall impact of roadkills in the long-term persistence of a population may depend on particular circumstances (e.g. time of year, weather), species, and 
road characteristics, which can act in synergy with each other. Therefore, future research should take into account all the factors along large temporal scales.

\section{Acknowledgments}

We thank the MOVE team that collected roadkill data: Ana Filipa Correia, Ana Galantinho, André Lourenço, Carmo Silva, Clara Ferreira, Cláudia Encarnação, Denis Medinas, Edgar Gomes, Filipe Carvalho, Frederico Mestre, Helena Marques, Luís Gomes, Mafalda Costa, Nelson Santos, Nelson Varela, Paula Gonçalves, Paulo Alves, Pedro Salgueiro, Sandra Alcobia, Tiago Marques, Vânia Neves, and many other volunteers. We are especially thankful to LabOR team (Carlos Godinho, Pedro Pereira, Pedro Salgueiro) for the help in the identification of some bird species.

\section{Funding}

This study was partly supported by two projects: "LIFE LINES - Linear Infrastructure Networks with Ecological Solutions" (LIFE14 NAT/PT/001081) and "POPCONNECT combining genetic field-based data to assess the effects of roads on landscape functional connectivity and population viability" (FCT PTDC/AAG-MAA/0372/2014). S.M. Santos and R. Lourenço were supported by Post-doctoral grants of Fundação para a Ciência e Tecnologia (FCT; SFRH/BPD/ 70124/2010 and SFRH/BPD/78241/2011, respectively).

\section{References}

Alonso, H., Coelho, R., Costa, J., Gouveia, C., Leitão, D., Machado, R. \& Teodósio, J. 2019. Relatório do Censo de Aves Comuns 2004-2018 [Report of the Common Bird Census 2004-2018]. Sociedade Portuguesa para o Estudo das Aves, Lisboa. www.spea.pt.

Benítez-López, A., Alkemade, R. \& Verweij, P.A. 2010. The impacts of roads and other infrastructure on mammal and bird populations: a meta-analysis. Biol. Conserv. 143: $1307-1316$.

BirdLife International. 2017. IUCN Red List for birds. http:// www.birdlife.org.

Brown, C.R. \& Brown, M.B. 2013. Where has all the road kill gone? Curr. Biol. 23: R233-R234.

Burnham, K.P. \& Anderson, D.R. 2002. Model Selection and Multimodel Inference: a practical information-theoretic approach. Springer-Verlag, New York.

Butchart, S.H., Walpole, M., Collen, B., van Strien, A., Scharlemann, J.PW., Almond, R.E.A., Baillie, J.E.M., Bomhard, B., Brown, C., Bruno, J., Carpenter, K.E., Carr, G.M., Chanson, J., Chenery, A.M., Csirke, J., Davidson, N.C., Dentener, F., Foster, M., Galli, A., Galloway, J.N., Genovesi, P., Gregory, R.D., Hockings, M., Kapos, V., Lamarque, J.F., Leverington, F., Loh, J., McGeoch, M.A., McRae, L., Minasyan, A., Morcillo, M.H., Oldfield, T.E.E., Pauly, D., Quader, S., Revenga, C., Sauer, J.R., Skolnik, B., Spear, D., Stanwell-Smith, D., Stuart, S.N., Symes, A., Tierney, M., Tyrrell, T.D., Vié, J.C. \& Watson, R. 2010. Global Biodiversity: indicators of recent declines. Science 328: 1164-1168.
Calvert, A., Bishop, C., Elliot, R., Krebs, E., Kydd, T., Machtans, C. \& Robertson, G. 2013. A synthesis of human-related avian mortality in Canada. Avian Conserv. Ecol. 8. doi:10.5751/ACE-00581-080211.

Carvalho, F. \& Mira, A. 2011. Comparing annual vertebrate road kills over two time periods, 9 years apart: a case study in Mediterranean farmland. Eur. J. Wildl. Res. 57: 157-174.

Catry, P., Costa, H., Elias, G. \& Matias, R. 2010. [Birds of Portugal - Ornithology of the Continental Territory]. Assírio \& Alvim, Lisboa (in Portuguese).

Cook, T.C. \& Blumstein, D.T. 2013. The omnivore's dilemma: diet explains variation in vulnerability to vehicle collision mortality. Biol. Conserv. 167: 310-315.

Ceballos, G., Ehrlich, P.R., Barnosky, A.D., García, A., Pringle, R.M. \& Palmer, T.M. 2015. Accelerated modern human-induced species losses: entering the sixth mass extinction. Sci. Adv. 1: e 1400253.

Clevenger, A.P., Chruszcz, B. \& Gunson, K.E. 2003. Spatial patterns and factors influencing small vertebrate fauna road-kill aggregations. Biol. Conserv. 109: 15-26.

Cramp, S. \& Brooks, D.J. 1992. Warblers. Handbook of the Birds of Europe, the Middle East and North Africa. The Birds of the Western Palearctic, Vol. VI, 396-405. Oxford University Press, Oxford.

Crick, H.Q. 2004. The impact of climate change on birds. Ibis. 146: $48-56$.

D’Amico, M., Román, J., De los Reyes, L. \& Revilla, E. 2015. Vertebrate road-kill patterns in Mediterranean habitats: who, when and where. Biol. Conserv. 191: 234-242.

De Laet, J. \& Summers-Smith, J.D. 2007. The status of the urban House Sparrow Passer domesticus in north-Western Europe: a review. J. Ornithol. 148: 275-278.

Dirzo, R. \& Raven, P.H. 2003. Global state of biodiversity and loss. Annu. Rev. Environ. Resour. 28: 137-167.

Dirzo, R., Young, H.S., Galetti, M., Ceballos, G., Isaac, N.J. \& Collen, B. 2014. Defaunation in the Anthropocene. Science 345: 401-406.

Donald, P.F., Green, R.E. \& Heath, M.F. 2001. Agricultural intensification and the collapse of Europe's farmland bird populations. Proc. R. Soc. B 268: 25-29.

Elphick, J. 2007. The Atlas of Bird Migration: Tracing the Great Journeys of the World's Birds. Firefly Books, Buffalo, NY.

Erritzøe, J., Mazgajski, T.D. \& Rejt, t. 2003. Bird casualties on European roads-a review. Acta Ornithol. 38: 77-93.

Fandos, G. \& Tellería, J.L. 2018. Range compression of migratory passerines in wintering grounds of the Western Mediterranean: conservation prospects. Bird Conserv. Int. 28: $462-474$.

Forman, R.T. 2003. Road Ecology: Science and Solutions. Island Press, Washington, DC.

Fuller, R.J., Noble, D.G., Smith, K.W. \& Vanhinsbergh, D. 2005. Recent declines in populations of woodland birds in Britain. Br. Birds 98: 116-143.

García-Herrera, R., Hernández, E., Barriopedro, D., Paredes, D., Trigo, R.M., Trigo, I.F. \& Mendes, M.A. 2007. The outstanding 2004/05 drought in the Iberian Peninsula: associated atmospheric circulation. J. Hydrometeorol. 8: 483-498.

Garriga, N., Franch, M., Santos, X., Montori, A. \& Llorente, G.A. 2017. Seasonal variation in vertebrate traffic casualties and its implications for mitigation measures. Landsc. Urban Plan. 157: 36-44. 
Gaston, K.J. 2010. Valuing common species. Science 327: 154-155.

Gaston, K.J. 2011. Common ecology. Bioscience 61: 354-362.

Girard, O. 2012. La mortalité aviaire due à la circulation routière en France (deuxième partie). Alauda 80: 3-12.

Gordo, O. 2007. Why are bird migration dates shifting? A review of weather and climate effects on avian migratory phenology. Clim. Res. 35: 37-58.

Grilo, C., Reto, D., Filipe, J., Ascensão, F. \& Revilla, E. 2014. Understanding the mechanisms behind road effects: linking occurrence with road mortality in owls. Anim. Conserv. 17: 555-564.

GTAN-SPEA. 2016. [Report of the Portugal NOCTUA Program (2009/10 - 2015/16)]. Sociedade Portuguesa para o Estudo das Aves, Lisboa (unpublished report, in Portuguese).

Hoffmann, M., Hilton-Taylor, C., Angulo, A., Böhm, M., Brooks, T.M., Butchart, S.H.M., Carpenter, K.E., Chanson, J., Collen, B., Cox, N.A., Darwall, W.R.T., Dulvy, N.K., Harrison, L.R., Katariya, V., Pollock, C.M., Quader, S., Richman, N.I., Rodrigues, A.S.L., Tognelli, M.F., Vié, J.C., Aguiar, J.M., Allen, D.J., Allen, G.R., Amori, G., Ananjeva, N.B., Andreone, F., Andrew, P., Ortiz, A.L.A., Baillie, J.E.M., Baldi, R., Bell, B.D., Biju, S.D., Bird, J.P., Black-Decima, P., Blanc, J.J., Bolaños, F., Bolivar-G, W., Burfield, I.J., Burton, J.A., Capper, D.R., Castro, F., Catullo, G., Cavanagh, R.D., Channing, A., Chao, N.L., Chenery, A.M., Chiozza, F., Clausnitzer, V., Collar, N.J., Collett, L.C., Collette, B.B., Fernandez, C.F.C, Craig, M.T., Crosby, M.J., Cumberlidge, N., Cuttelod, A., Derocher, A.E., Diesmos, A.C., Donaldson, J.S., Duckworth, J.W., Dutson, G., Dutta, S.K., Emslie, R.H., Farjon, A., Fowler, S., Freyhof, J., Garshelis, D.L., Gerlach, J., Gower, D.J., Grant, T.D., Hammerson, G.A., Harris, R.B., Heaney, L.R., Hedges, S.B., Hero, J.M., Hughes, B., Hussain, S.A., Icochea, M.J., Inger, R.F., Ishii, N., Iskandar, D.T., Jenkins, R.K.B., Kaneko, Y., Kottelat, M., Kovacs, K.M., Kuzmin, S.L., La Marca, E., Lamoreux, J.F., Lau, M.W.N., Lavilla, E.O., Leus, K., Lewison, R.L., Lichtenstein, G., Livingstone, S.R., Lukoschek, V., Mallon, D.P., McGowan, P.F.K., McIvor, A., Moehlman, P.D., Molur, S., Alonso, A.M., Musick, J.A., Nowell, K., Nussbaum, R.A., Olech, W., Orlov, N.L., Papenfuss, T.J., Parra-Olea, G., Perrin, W.F., Polidoro, B.A., Pourkazemi, M., Racey, P.A., Ragle, J.S., Ram, M., Rathbun, G., Reynolds, R.P., Rhodin, A.G.J., Richards, S.J., Rodríguez, L.O., Ron, S.R., Rondinini, C., Rylands, A.B., de Mitcheson, Y.S., Sanciangco, J.C., Sanders, K.L., Santos-Barrera, G., Schipper, J., SelfSullivan, C., Shi, Y., Shoemaker, A., Short, F.T., SilleroZubiri, C., Silvano, D.L., Smith, K.G., Smith, A.T., Snoeks, J., Stattersfield, A.J., Symes, A.J., Taber, A.B., Talukdar, B.K., Temple, H.J., Timmins, R., Tobias, J.A., Tsytsulina, K., Tweddle, D., Ubeda, C., Valenti, S.V., van Dijk, P.P., Veiga, L.M., Veloso, A., Wege, D.C., Wilkinson, M., Williamson, E.A., Xie, F., Young, B.E., Akçakaya, H.R., Bennun, L., Blackburn, T.M., Boitani, L., Dublin, H.T., da Fonseca, G.A.B., Gascon, C., Lacher Jr, T.E., Mace, G.M., Mainka, S.A., McNeely, J.A., Mittermeier, R.A., Reid, G.M., Rodriguez, J.P., Rosenberg, A.A., Samways, M.J., Smart, J., Stein, B.A. \& Stuart, S.N. 2010. The impact of conservation on the status of the world's vertebrates. Science 330: 1503-1509.
Holm, T.E. \& Laursen, K. 2011. Car traffic along hedgerows affects breeding success of great Tits Parus major. Bird Study 58: 512-515.

del Hoyo, J., Elliott, A., Sargatal, J., Christie, D.A. \& de Juana, E. 2015. Handbook of the Birds of the World Alive. Lynx Edicions, Barcelona.

Husby, M. 2017. Traffic influence on roadside bird abundance and behaviour. Acta Ornithol. 52: 93-103.

Inger, R., Gregory, R., Duffy, J.P., Stott, I., Voříšek, P. \& Gaston, K.J. 2015. Common European birds are declining rapidly while less abundant species' numbers are rising. Ecol. Lett. 18: 28-36.

IPMA. 2017a. [Climatic norms/Évora 1981-2000]. Instituto Português do Mar e da Atmosfera, IP, Portugal. http:// www.ipma.pt (in Portuguese).

IPMA. 2017b. [Climatic characterization/Year 2005]. Instituto Português do Mar e da Atmosfera, IP, Portugal. http://www. ipma.pt (in Portuguese).

ITF. 2016. "Portugal", in Road Safety Annual Report 2016. OECD Publishing, Paris.

IUCN (Int. Union Conserv. Nat. Resour.). 2014. The IUCN Red List. http://www.iucnredlist.org.

Jack, J. 2013. Investigating the role of mortality in explaining the negative road effect on birds. PhD Thesis, Carleton University.

Jonzén, N., Ergon, T., Lindén, A. \& Stenseth, N.C. 2007. Bird migration and climate. Clim. Res. 35: 1-2.

Kociolek, A.V., Clevenger, A.P., St Clair, C.C. \& Proppe, D.S. 2011. Effects of road networks on bird populations. Conserv. Biol. 25: 241-249.

Korner-Nievergelt, F., Behr, O., Brinkmann, R., Etterson, M.A., Huso, M.M., Dalthorp, D., Korner-Nievergelt, P., Roth, T. \& Niermann, I. 2015. Mortality estimation from carcass searches using the Rpackage carcass-a tutorial. Wildlife. Biol. 21: 30-43.

Korner-Nievergelt, F., Niermann, I., Behr, O., Etterson, M.A., Brinkmann, R., Korner, P., Hellriegel, B. \& Roth, T. 2014. Package 'carcass'. CRAN.

Kuitunen, M.T., Viljanen, J., Rossi, E. \& Stenroos, A. 2003. Impact of busy roads on breeding success in Pied Flycatchers Ficedula hypoleuca. Environ. Manage. 31: 0079-0085.

Langen, T.A., Ogden, K.M. \& Schwarting, L.L. 2009. Predicting hotspots of herpetofauna road mortality along highway networks. J. Wild. Manage. 73: 104-114.

Laursen, K. 1981. Birds on roadside verges and the effect of mowing on frequency and distribution. Biol. Conserv. 20: $59-68$.

Lima, S.L. \& Dill, L.M. 1990. Behavioral decisions made under the risk of predation: a review and prospectus. Can. J. Zool. 68: 619-640.

Loss, S.R., Will, T. \& Marra, P.P. 2013. The impact of freeranging domestic cats on wildlife of the United States. Nature Commun. 4: 1396.

Loss, S.R., Will, T. \& Marra, P.P. 2014. Estimation of birdvehicle collision mortality on US roads. J. Wildl. Manage. 78: 763-771.

Loss, S.R., Will, T. \& Marra, P.P. 2015. Direct mortality of birds from anthropogenic causes. Ann. Ver. Ecol. Evol. Syst. 46: 99-120.

Malo, J.E., Suarez, F. \& Díez, A. 2004. Can we mitigate animal-vehicle accidents using predictive models? J. Appl. Ecol. 41: 701-710. 
Meirinho, A., Leal, A., Marques, A.T., Fagundes, A.I., Sampaio, H., Costa, J. \& Leitão, D. 2013. [The status of common bird species in Portugal 2011: report of the Census of Common Birds project]. Sociedade Portuguesa para o Estudo das Aves, Lisboa (unpublished report, in Portuguese).

Møller, A.P., Erritzøe, H. \& Erritzøe, J. 2011. A behavioural ecology approach to traffic accidents: Interspecific variation in causes of traffic casualties among birds. Zool. Res. 32: 115-127.

Morelli, F., Beim, M., Jerzak, L., Jones, D. \& Tryjanowski, P. 2014. Can roads, railways and related structures have positive effects on birds?-a review. Transp. Res. D Transp. Environ. 30: 21-31.

Morelli, F., Jerzak, L., Pruscini, F., Santolini, R., Benedetti, Y. \& Tryjanowski, P. 2015. Testing bird response to roads on a rural environment: A case study from central Italy. Acta Oecol. 69: 146-152.

Orłowski, G. 2005. Factors affecting road mortality of the Barn Swallows Hirundo rustica in farmland. Acta Ornithol. 40: 117-125.

Orłowski, G. 2008. Roadside hedgerows and trees as factors increasing road mortality of birds: implications for management of roadside vegetation in rural landscapes. Landsc. Urban Plan. 86: 153-161.

Parris, K. \& Schneider, A. 2009. Impacts of traffic noise and traffic volume on birds of roadside habitats. Ecol. Soc. 14: 29.

PECBMS. 2019. PanEuropean Common Bird Monitoring Scheme (EBCC/BirdLife/RSPB/CSO). https://pecbms.info/ trends-and-indicators/species-trends/sort/taxonomy/ species/sylvia-atricapilla/.

Pinto, M., Rocha, P. \& Moreira, F. 2005. Long-term trends in great bustard (Otis tarda) populations in Portugal suggest concentration in single high quality area. Biol. Conserv. 124: 415-423.

Polak, M., Wiącek, J., Kucharczyk, M. \& Orzechowski, R. 2013. The effect of road traffic on a breeding community of woodland birds. Eur. J. For. Res. 132: 931-941.

Ramsden, D. 2003. Barn Owls and Major Roads: Results and Recommendations from a 15-Year Research Project. Barn Owl Trust, Ashburton.

R Development Core Team. 2016. R: A language and environment for statistical computing. R Foundation for Statistical Computing, Vienna, Austria. http://www.Rproject.org.

Reijnen, R. \& Foppen, R. 2006. Impact of road traffic on breeding bird populations. In J. Davenport \& J. L. Davenport. (ed) The Ecology of Transportation: managing mobility for the environment. Environmental pollution, Vol 10: 255-274. Springer, Dordrecht.

Reijnen, R., Foppen, R. \& Veenbaas, G. 1997. Disturbance by traffic of breeding birds: evaluation of the effect and considerations in planning and managing road corridors. Biodivers. Conserv. 6: 567-581.

Robinson, R.A., Leech, D.I., Massimino, D., Woodward, I., Eglington, S.M., Marchant, J.H., Sullivan, M.J.P., Barimore, C., Hammond, M.J., Harris, S.J., Noble, D.G., Walker, R.H. \& Baillie, S.R. 2015. BirdTrends 2015: trends in numbers, breeding success and survival for UK breeding birds. Research Report 678. BTO, Thetford.
Rosa, C.A. \& Bager, A. 2012. Seasonality and habitat types affect roadkill of neotropical birds. J. Environ. Manage. 97: 1-5.

Rosenberg, K.V., Dokter, A.M., Blancher, P.J., Sauer, J.R., Smith, A.C., Smith, P.A., Stanton, J.C., Panjabi, A., Helft, L., Parr, M. \& Marra P.P. 2019. Decline of North American avifauna. Science 366: 120-124.

Salgueiro, P.A., Mira, A., Rabaça, J.E. \& Santos, S.M. 2018. Identifying critical thresholds to guide management practices in agro-ecosystems: insights from bird community response to an open grassland-to-forest gradient. Ecol. Indic. 88: 205-213.

Santos, S.M., Carvalho, F. \& Mira, A. 2011. How long do the dead survive on the road? Carcass persistence probability and implications for road-kill monitoring surveys. PLoS One 6: e25383.

Santos, S.M., Lourenço, R., Mira, A. \& Beja, P. 2013. Relative effects of road risk, habitat suitability, and connectivity on wildlife roadkills: the case of Tawny Owls (Strix aluco). PloS One 8: e79967.

Santos, S.M., Mira, A., Salgueiro, P.A., Costa, P., Medinas, D. \& Beja, P. 2016. Avian trait-mediated vulnerability to road traffic collisions. Biol. Conserv. 200: 122-130.

Şekercioğlu, ÇH, Daily, G.C. \& Ehrlich, P.R. 2004. Ecosystem consequences of bird declines. Proc. Natl. Acad. Sci. USA 101: 18042-18047.

SEO/BirdLife. 2014. [SEO/BirdLife tracking programs in 2013. 60 Years of citizen science of SEO/BirdLife]. SEO/BirdLife, Madrid (in Spanish).

Silva, C., Grilo, C. \& Mira, A. 2008. Modelling owl mortality on roads of Alentejo (southern Portugal). Airo 18: 3-12.

Silva, C.C., Lourenço, R., Godinho, S., Gomes, E., SabinoMarques, H., Medinas, D., Neves, V., Carmo, S., Rabaça, J.E. \& Mira, A. 2012. Major roads have a negative impact on the Tawny Owl Strix aluco and the little Owl Athene noctua populations. Acta Ornithol. 47: 47-54.

Smith-Patten, B.D. \& Patten, M. 2008. Diversity, seasonality, and context of mammalian roadkills in the southern great Plains. Environ. Manage. 41: 844-852.

Summers, P.D., Cunnington, G.M. \& Fahrig, L. 2011. Are the negative effects of roads on breeding birds caused by traffic noise? J. Appl. Ecol. 48: 1527-1534.

Tabachnick, B. \& Fidell, L. 1996. Using Multivariate Statistics. Pearson Education, Boston.

Teixeira, F.Z., Coelho, A.V.P., Esperandio, I.B. \& Kindel, A. 2013. Vertebrate road mortality estimates: effects of sampling methods and carcass removal. Biol. Conserv. 157: 317-323.

White, T.C.R. 2008. The role of food, weather and climate in limiting the abundance of animals. Biol. Rev. Camb. Philos. Soc. 83: 227-248.

Wood, S. 2017. Mixed GAM Computation Vehicle with MGCV/ AIC/REML Smoothness Estimation, Version 1: 8-17.

Zuur, A.F., Ieno, E.N. \& Elphick, C.S. 2010. A protocol for data exploration to avoid common statistical problems. Methods Ecol. Evol. 1: 3-14.

Zuur, A., Ieno, E.N. \& Meesters, E. 2009. A Beginner's Guide to $R$. Springer Science \& Business Media, New York.

Zuur, A., Ieno, E.N. \& Smith, G.M. 2007. Analysing Ecological Data. Springer Science \& Business Media, New York 